\title{
Torque ripple minimization in direct torque control at low- speed operation using alternate switching technique
}

\author{
Muhammad Zaid Aihsan ${ }^{1}$, Auzani Jidinn, , Azrita Alias ${ }^{2,3}$, Siti Azura Ahmad Tarusan ${ }^{2,3}$, \\ Zuraidi Md Tahir ${ }^{2,3}$, Tole Sutikno ${ }^{4,5}$ \\ ${ }^{1}$ Faculty of Electrical Engineering Technology, University Malaysia Perlis (UniMAP), Perlis, Malaysia \\ ${ }^{2}$ Faculty of Electrical Engineering, Universiti Teknikal Malaysia Melaka (UTeM), Malacca, Malaysia \\ ${ }^{3}$ Power Electronics and Drives Research Group, CeRIA, UTeM, Malacca, Malaysia \\ ${ }^{4}$ Department of Electrical Engineering, Universitas Ahmad Dahlan, Yogyakarta, Indonesia \\ ${ }^{5}$ Embedded System and Power Electronics Research Group (ESPERG), Yogyakarta, Indonesia
}

\begin{tabular}{l} 
Article Info \\
\hline Article history: \\
Received Nov 9, 2021 \\
Revised Jan 14, 2022 \\
Accepted Feb 10, 2022 \\
\hline Keywords: \\
AC motor drives \\
Alternate switching \\
Direct torque control \\
Torque ripple \\
Two-level inverter
\end{tabular}

\begin{abstract}
Direct torque control (DTC) of induction motor is prominent to offer instant torque and flux control with a simple control structure. However, this scheme suffers from two major drawbacks namely high torque ripple and variable switching frequency of the inverter, especially during low-speed operation. During the low-speed condition, the positive torque slope is very steep and torque overshoot frequently occurs, resulting in the torque ripple becoming of great significance. This paper proposes a novel and effective technique to reduce the torque ripple by integrating the alternate switching technique to the inverter switching status to limit the torque slope surge. By varying the frequency and duty cycle of the alternate switching, the surge rate can be controlled resulting in the chances of overshoots, and selection of reverse voltage vector can be avoided. The feasibility of the proposed technique has been validated using MATLAB/Simulink software and through experimental results. The results show the proposed alternate switching technique minimizes over $40 \%$ reduction in the torque ripple while maintaining the simple structure of DTC.
\end{abstract}

This is an open access article under the $\underline{C C B Y-S A}$ license.

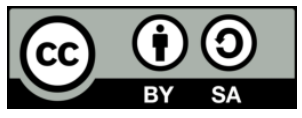

\section{Corresponding Author:}

Muhammad Zaid Aihsan

Faculty of Electrical Engineering Technology, University Malaysia Perlis

02600 Arau, Perlis, Malaysia

Email: zaid@unimap.edu.my

\section{INTRODUCTION}

Direct torque control (DTC) was developed over a decade ago to provide quick and accurate dynamic torque response and flux control with a simple construction [1]. This method is well-known for its control robustness [2]-[14]. It relies less on machine parameters [15], [16] and does not require the complicated speed encoder, inner current regulation loop and field orientation block [17]. However, this system addressed two main problems namely high torque ripple and the variation of the switching frequency of the inverter according to operating conditions [18]-[27].

Many methods have been proposed in recent years with various approaches to tackle these issues. For example, the implementation of the direct torque control space vector modulation (DTC-SVM) technique [28][54]. This technique ensures that the inverter switching frequency remains constant and combines with the benefits of the DTC method to improves the torque ripple. However, calculation of reference voltage space vectors is required and complex to solve. Another technique namely adjustable hysteresis band presented in [47], [55], [56], enables the reduction of the hysteresis band size resulting in accurate torque regulation, 
particularly when the pre-set sampling time is small. However, in practice, dSPACE-based DTC operates at a minimum sample rate of $50 \mu \mathrm{s}$, which may cause the torque to travel between the upper and lower band vigorously, resulting in overshoot and undershoot. In addition, the system will often select the reverse voltage vector during overshoot and undershoot, which may cause the system to produce the common DTC problem, namely variable switching frequency [57]-[59]. Integrating the DTC with predictive control has lately received much attention due to its capacity to minimise torque ripple and operate at a constant switching frequency [60]-[62]. However, this system demands a correct selection of weighting factors as incorrect weighting factors result in a greater torque and flux ripple. Several studies covered in [63]-[66] mainly use the duty cycle control concept employing an active voltage vector for a portion of a control period, which then switches to a zerovoltage vector for the remainder of the control cycle.

This paper proposes a novel technique to minimize the torque ripple by integrating the alternate digital pulsation into the inverter switching status of DTC. This technique is a simple and effective method as it improves the torque rate to travel within the hysteresis band precisely, thus avoiding the need for reverse voltage vectors. Theoretically, the rate of torque slope can be controlled by adjusting the DC link voltage manually. However, it is not practical for real DTC applications such as electric vehicle (EV) where the real EV uses supercapacitor or batteries as its main supply. The proposed technique practically limits the DC link voltage by using alternate digital pulsation in the form of duty cycle. This study is verified through simulation (MATLAB/Simulink) as well as experimental setup using dSPACE 1104 board and compared with conventional DTC scheme. The proposed structure of DTC is briefly described in section 2 of the paper. Section 3 demonstrates the operation of the torque under the proposed scheme. Section 4 presents simulation and experimental findings for the conventional and proposed techniques, respectively. Finally, section 5 gives the conclusions to the paper.

\section{THE PROPOSED DTC BASED ON AN ALTERNATE SWITCHING TECHNIQUE}

The conventional DTC proposed [1] is straightforward. It combines of subsystems comprised of a pair of hysteresis comparators, torque and flux calculators, a look-up table, and a voltage-source inverter (VSI). In the proposed DTC system, each of the subsystems are described in terms of space vectors by the following equations written in stator stationary reference frame:

$$
\begin{aligned}
& v_{s}=\mathrm{r}_{s} i_{s}+\frac{\mathrm{d} \Psi_{s}}{\mathrm{dt}} \\
& 0=\mathrm{r}_{r} i_{r}-\mathrm{j} \omega_{r} \Psi_{r}+\frac{\mathrm{d} \Psi_{r}}{\mathrm{dt}} \\
& \Psi_{s}=\mathrm{L}_{s} i_{s}+\mathrm{L}_{m} i_{r} \\
& \Psi_{r}=\mathrm{L}_{r} i_{r}+\mathrm{L}_{m} i_{s} \\
& T_{e}=\frac{3}{2} \mathrm{p}\left|\Psi_{s}\right|\left|\mathrm{i}_{s}\right| \sin \delta
\end{aligned}
$$

where $\mathrm{p}$ denotes the number of pole pairs, $\omega_{r}$ denotes the rotor electric angular speed in $\mathrm{rad} / \mathrm{s}, L_{s}, L_{r}$ and $L_{m}$ denote the motor inductances, and $\delta$ is the angle between the stator flux linkage and the stator current space vectors. Based on (1), the $d^{s}-$ and $q^{s}-$ axis stator flux in a stationary reference frame may be expressed as:

$$
\begin{aligned}
& \Psi_{\mathrm{s}, \mathrm{d}}{ }^{s}=\int\left(v_{\mathrm{s}, \mathrm{d}}{ }^{s}-\mathrm{i}_{\mathrm{s}, \mathrm{d}}{ }^{s} r_{s}\right) \mathrm{dt} \\
& \Psi_{\mathrm{s}, \mathrm{q}}{ }^{s}=\int\left(v_{\mathrm{s}, \mathrm{q}}{ }^{s}-\mathrm{i}_{\mathrm{s}, \mathrm{q}}{ }^{s} r_{s}\right) \mathrm{dt}
\end{aligned}
$$

The scope for this study will use the standard two-level inverter. Therefore the (6a) and (6b) can be further expressed in term of switching states $S_{a}, S_{b}$ and $S_{c}$.

$$
\begin{aligned}
& v_{\mathrm{s}, \mathrm{d}}{ }^{s}=\frac{1}{3} V_{\mathrm{dc}}\left(2 \mathrm{~S}_{a}-\mathrm{S}_{b}-\mathrm{S}_{c}\right) \\
& v_{\mathrm{s}, \mathrm{q}}{ }^{s}=\frac{1}{\sqrt{3}} V_{\mathrm{dc}}\left(S_{b}-\mathrm{S}_{c}\right)
\end{aligned}
$$

The electromagnetic torque given in (5) can be rewritten in $d^{S}-$ and $q^{S}-$ coordinates as: 


$$
T_{e}=\frac{3}{2} p\left(\Psi_{s, \mathrm{~d}}^{s} \mathrm{i}_{\mathrm{s}, \mathrm{q}}^{s}-\Psi_{\mathrm{s}, \mathrm{q}}^{s} \mathrm{i}_{\mathrm{s}, \mathrm{d}}^{s}\right)
$$

The (1) to (8) are modelled as in Figure 1 with an additional proposed alternate switching strategy. The proposed technique is in the form of a duty cycle will be added to the inverter switching state from the look-up table. By default, the conventional DTC system working principle is based on the output stator voltage applied based on the selection of the switching states $S_{a}, S_{b}$ and $S_{c}$ obtained from the look-up table. These switching states are chosen based on the need to increase or reduce the torque and stator flux, as well as the stator flux position.

The alternate switching technique will not affect the nature of the DTC concept; instead, it will control the rate of torque to travel inside the hysteresis band. As shown in Figure 2, the suggested method utilized the precise signal from the inverter switching state to integrate with square wave pulsation using an AND logic gate. The newly generated signals are defined as $\Delta \mathrm{S}_{a}, \Delta \mathrm{S}_{b}$ and $\Delta \mathrm{S}_{c}$ while the timing diagram for each signal is shown in Figure 3. The new signals are produced in the same sequence as the original DTC switching status, but with a different switching pattern.

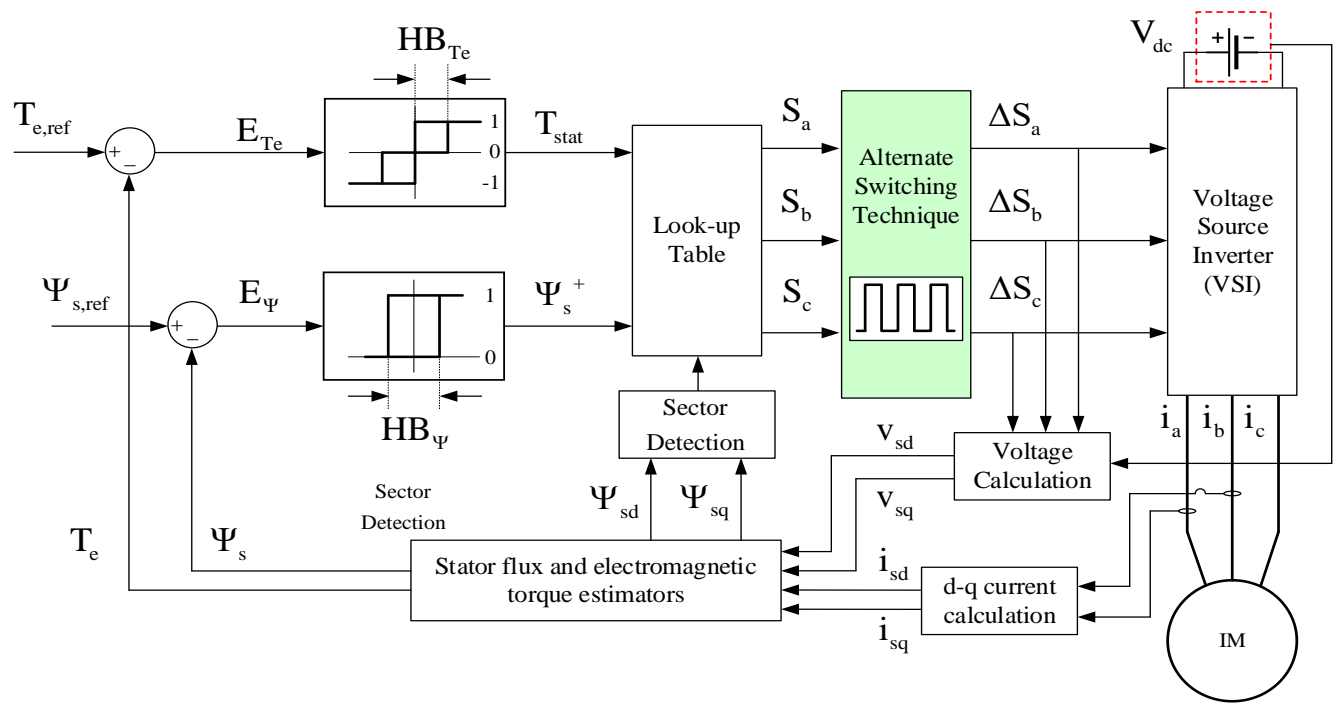

Figure 1. Proposed system with alternate switching technique

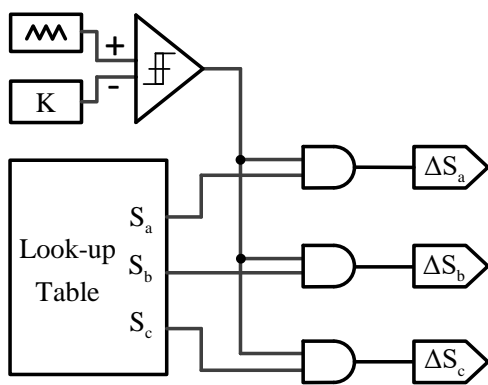

Figure 2. Proposed alternate switching technique

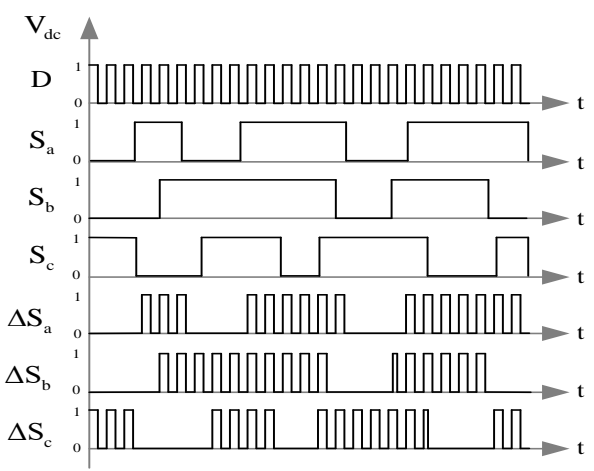

Figure 3. Alternated DTC switching signals

\section{OPERATION OF TORQUE USING ALTERNATE SWITCHING TECHNIQUE}

Whenever the induction motor is operated at a low speed, the low back electromotive force (EMF) may cause higher torque increment rates, resulting in an extremely steep torque slope to the point that torque excursion can be driven far beyond the hysteresis band. This situation generates a significant torque ripple, which must be corrected, particularly at low speeds [67]-[69]. Using the alternate switching technique injects the active voltage vector in the sequencing/alternate scheme, improving the performance for both torque and stator flux as it simultaneously limits the torque excursion within the hysteresis band. Furthermore, this allows 
the stator flux to move in the better zig-zag pattern, thus avoiding selecting a reserve voltage vector. To analyse the effect of voltage vectors on the torque ripple in DTC-hysteresis-based drives, the torque equation will be written in terms of stator and rotor flux magnitudes as (9).

$$
T_{e}=\frac{3}{2} p \frac{L_{m}}{\sigma \mathrm{L}_{s} L_{r}} \Psi_{s} \Psi_{r} \sin \delta_{\mathrm{sr}}
$$

where $\sigma$ is the total leakage factor, while $\delta_{s r}$ is the angle between the stator and rotor flux vectors. This angle difference is critical in regulating the output torque.

Following from here, in (9) can be rewritten by considering sampling time for every cycle, $T_{\text {sp }}$ given as:

$$
\begin{aligned}
& \Psi_{S(\mathrm{k}+1)}=\Psi_{S(k)}+\left[-\frac{R_{S}}{\sigma \mathrm{L}_{S}} \Psi_{S(k)}+\frac{R_{S} L_{M}}{\sigma \mathrm{L}_{S} L_{r}} \Psi_{r(k)}+\mathrm{v}_{S}\right] T_{\mathrm{sp}} \\
& \Psi_{r(\mathrm{k}+1)}=\Psi_{r(k)}+\left[\frac{R_{r} L_{M}}{\sigma \mathrm{L}_{S} L_{r}} \Psi_{S(k)}+\pi\left(\mathrm{j} \omega_{r}-\frac{R_{S}}{\sigma \mathrm{L}_{S}}\right) \Psi_{r(k)}\right] T_{\mathrm{sp}}
\end{aligned}
$$

By substituting (10) and (11) into discrete form of (9), torque slopes during increment and decrement can be expressed as:

$$
\begin{aligned}
& T_{e}{ }^{+}=-\mathrm{T}_{e(k)}\left(\frac{R_{S}}{\sigma \mathrm{L}_{s}}+\frac{R_{r}}{\sigma \mathrm{L}_{r}}\right)+\frac{3}{2} \frac{p}{2} \frac{L_{m}}{\sigma \mathrm{L}_{s} L_{r}} i\left[\left(v_{s} \bullet \Psi_{r}\right)-\mathrm{j} \omega_{r}\left(\Psi_{s} \bullet \Psi_{r}\right)\right] \\
& T_{e}{ }^{-}=-\mathrm{T}_{e_{(k)}}\left(\frac{R_{S}}{\sigma \mathrm{L}_{s}}+\frac{R_{r}}{\sigma \mathrm{L}_{r}}\right)-\frac{3}{2} \frac{p}{2} \frac{L_{m}}{\sigma \mathrm{L}_{s} L_{r}} i\left[\mathrm{j} \omega_{r}\left(\Psi_{S} \bullet \mathrm{j} \Psi_{r}\right)\right]
\end{aligned}
$$

Moreover, the percentage of torque ripple can be calculated as follows:

$$
\% \text { of torque ripple }=\frac{\Delta \text { torque ripple }}{\text { average torque }} \times 100 \%
$$

Figure 4 shows the torque slope condition, and the Figure 4 (a) illustrated the conventional DTC torque increment, $T_{e}{ }^{+}$and torque decrement, $T_{e}{ }^{-}$within one complete cycle of sampling time, $T_{\mathrm{sp}}$. In each sampling time, the torque slope varies according to the duration of varies according to the duration of $T_{s}$ of injected voltage vector, $v_{s}$. Figure $4(\mathrm{~b})$ shows how the proposed alternate switching technique allows the active voltage vector to be in the form of an alternating sequence which it can limit the torque excursion rate. The alternate switching technique makes the value of $T_{s}$ become way smaller, thus changing the state between positive torque slope and negative torque slope in a short time due to the alternating active voltage vector. The alternate switching technique uses the square waveform with a 50\% duty ratio for ON-state and OFF-state respectively. For this study, the switching frequency used for the alternate switching is $2.5 \mathrm{kHz}$ resulting in the rise and fall in the period of $200 \mu$ s during ON-state and OFF-state respectively. Using this concept allows limiting the torque excursion within the torque reference, $T_{e}{ }^{*}$.

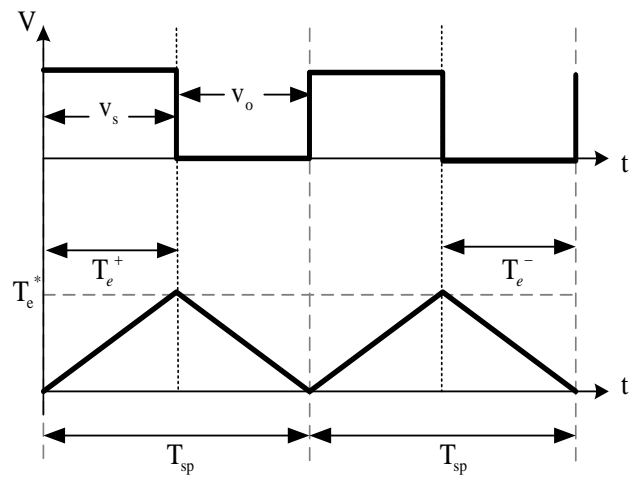

(a)

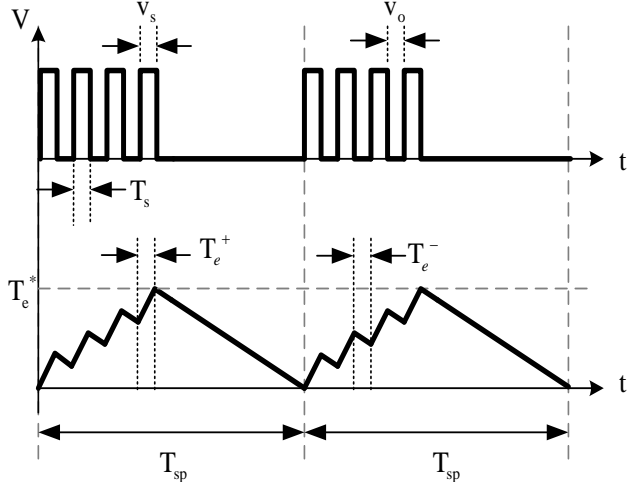

(b)

Figure 4. Torque slope condition (a) conventional DTC (b) proposed alternate DTC 
The complete comparison of the conventional DTC to the proposed DTC demonstrated in Figure 5. In the conventional DTC, the active voltage vectors, $V_{s}$ tend to generate the different variations of torque slopes which causes the high torque ripples and variable switching frequency. When the torque excursion is too high and exceed the hysteresis band, the system starts to choose reverse voltage vectors, $-V_{s}$ to ensure the sudden decrement in the torque magnitude. However, this will cause the torque to become unstable in a short period of time, increasing the probability of selecting reserve voltage vectors. The proposed DTC employs an alternate switching technique that allows the torque slopes to move in a zig-zag pattern, thus limiting the rate of excursion and resulting in a magnitude of torque within the torque estimation range. Since the magnitude of the torque does not exceed the hysteresis band limit, no reverse voltage vector selection is required. This enables the DTC system to operate with regulated torque performance, resulting in less ripple and an improvement in frequency variations.

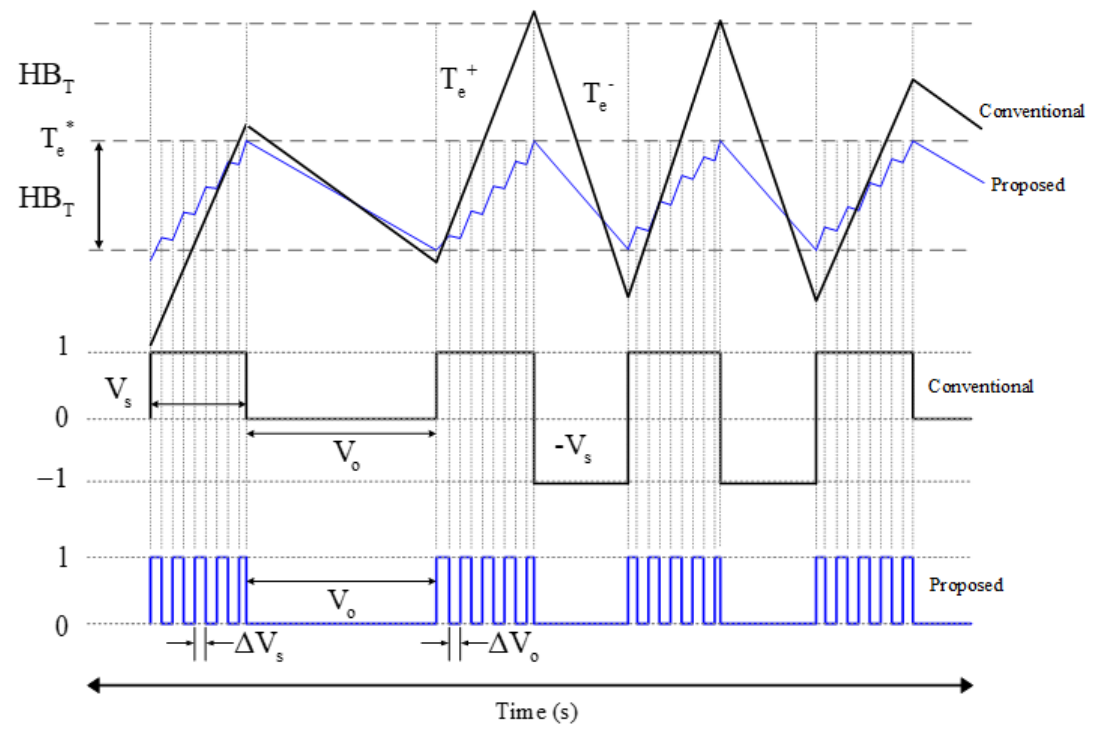

Figure 5. The comparison between conventional DTC and proposed DTC using alternate switching technique

\section{RESULTS AND DISCUSSION}

The efficacy of the proposed alternate switching technique was simulated using MATLAB/Simulink. Here, an experimental evaluation was carried out to show workability in the real DTC drive system. The parameters and specifications used for this experimental setup are shown in Table 1. Since this study focuses on the low-speed application, the induction motor speed is set to $30 \mathrm{rad} / \mathrm{s}$, while the selected torque is $1.5 \mathrm{Nm}$ for both conventional and proposed alternate switching techniques. Furthermore, rated torque and flux are $4 \mathrm{Nm}$ and $0.8452 \mathrm{~Wb}$, respectively. The conventional DTC and the proposed method will be evaluated using two different hysteresis band sizes of $0.5 \mathrm{Nm}$ and $0.25 \mathrm{Nm}$.

Table 1. Induction Machine parameters

\begin{tabular}{lc}
\hline \multicolumn{2}{c}{ Induction Machine } \\
Parameter & Value \\
\hline Rated power, $\mathrm{P}$ & $1.1 \mathrm{~kW}$ \\
Rated speed, $\omega_{\mathrm{m} \text { rated }}$ & $2800 \mathrm{rpm}$ \\
Stator Resistance, $R_{s}$ & $6.1 \Omega$ \\
Rotor Resistance, $R_{r}$ & $6.2293 \Omega$ \\
Mutual Inductance, $L_{m}$ & $0.4634 \mathrm{mH}$ \\
Rotor self inductance, $L_{r}$ & $0.47979 \mathrm{mH}$ \\
Stator self inductance, $L_{s}$ & $0.47979 \mathrm{mH}$ \\
Number of pole pairs, $\mathrm{p}$ & 2 \\
Conventional and alternate switching of DTC system \\
Torque Hysteresis band, $\mathrm{HB}_{\mathrm{Te}}$ & $0.25 \mathrm{Nm}$ and $0.5 \mathrm{Nm}$ \\
Flux Hysteresis band, $\mathrm{HB}_{\Psi}$ & $0.0080 \mathrm{~Wb}$ \\
\hline
\end{tabular}




\subsection{Simulation results}

In this study, the focus is mainly on measuring the torque ripple's performance when using the alternate switching technique. Figure 6 shows the results of torque, phase voltages, and the condition of inverter switching status with the hysteresis band size 0.5. Initially, it is conducted in the conventional DTC method for the duration of 1.04 seconds before the alternate switching technique is employed. It is noticeable that the behaviour of phase voltage and inverter switching status started to be in high pulsation condition after 1.04 seconds, and the ripple of torque started to reduce when the alternate switching was initiated. Figure 6 (a) shows in full scale, and the magnified version is shown in Figure 6 (b). The condition of torque in the conventional DTC is steeper and can easily reach the torque reference in a very short time. For the proposed technique, the torque is less steep, while the condition of torque slope imitates the pulsation pattern of the alternate switching technique. This feature allows the rate of torque to be controlled directly without adjusting the DC-link voltage. Moreover, the potential of torque to overshoot over the hysteresis band can be reduced efficiently. The uniform alternate voltage generation from the proposed technique allows the condition of increment and decrement of torque slope to travel within the hysteresis band with less overshoot and undershoot condition [54].

The performance of the alternate switching is further tested with the lower hysteresis band size as the behaviour of torque using the alternate switching technique shown in Figure 7. It has a lower torque slope, while the rate of steepness can be controlled evenly for every peak cycle. Figure 7 (a) shows the same results of torque, phase voltages, and the inverter switching status with the hysteresis band size 0.25 . The magnified version can be observed in Figure 7 (b). It can be observed that the condition of torque during conventional DTC greatly suffers in high ripple conditions resulting in the selection of reverse voltage vectors occurring frequently.

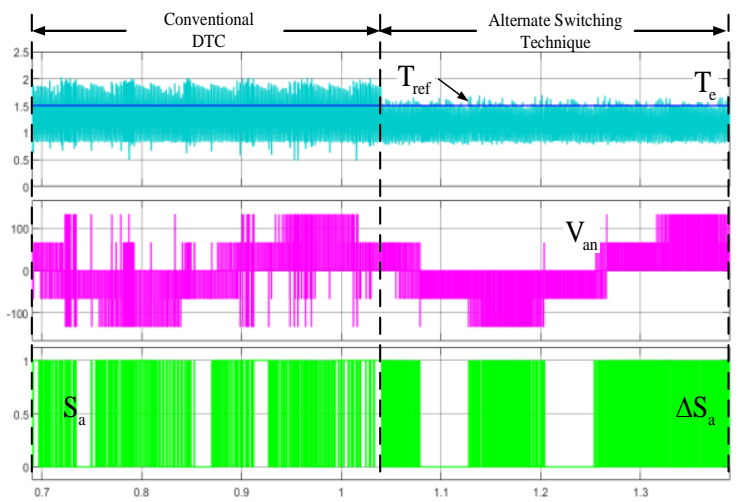

(a)

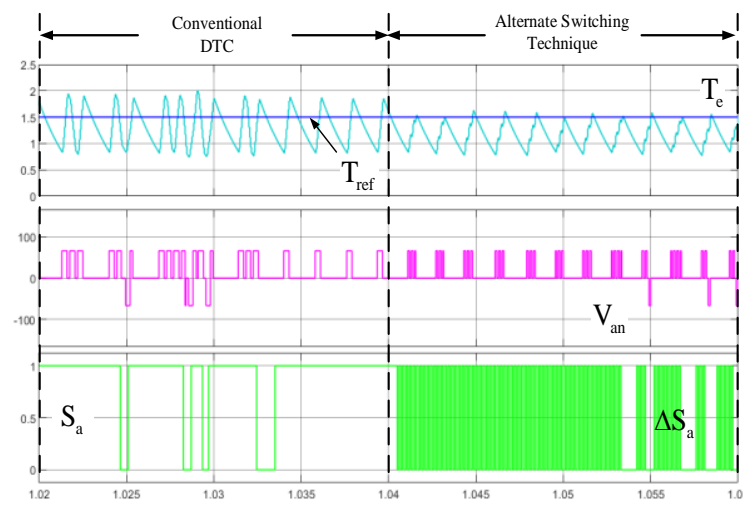

(b)

Figure 6. The performance of torque, phase voltage and inverter switching status under hysteresis band size $0.5 \mathrm{Nm}$ (a) full scale and (b) magnified scale

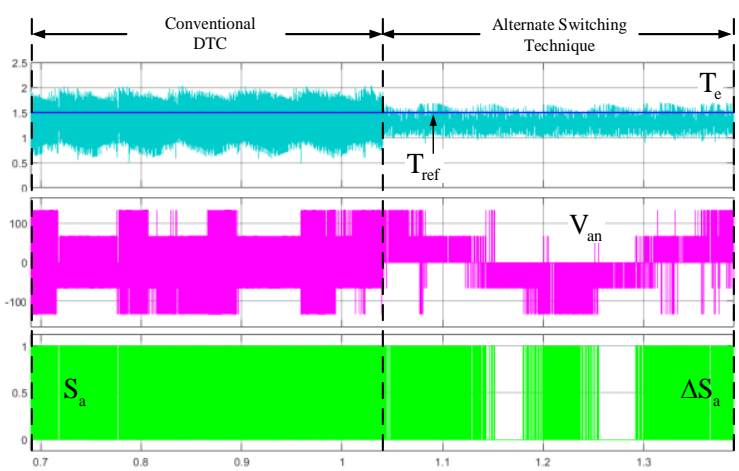

(a)

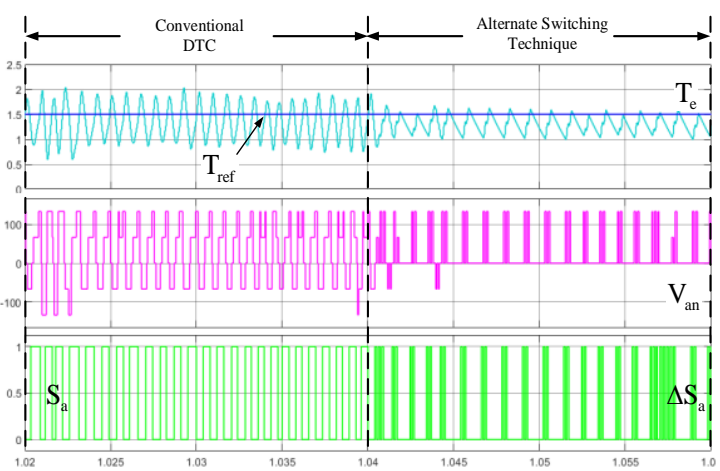

(b)

Figure 7. The performance of torque, phase voltage and inverter switching status under hysteresis band size $0.25 \mathrm{Nm}$ (a) full scale and (b) magnified scale 
This condition is due to the torque being extremely steep during the low-speed condition and the small size of the hysteresis band, allowing the torque to be easily driven far beyond the hysteresis band regularly [16], [68]. However, when the alternate switching technique is utilized, the condition of torque ripple has a massive reduction, and the selection of reserve voltage vector is also reduced.

Figure 6 and Figure 7 show that the conventional DTC suffers from high selection of reverse voltage vectors and the waveform of phase voltage is not properly generated. The condition of phase voltage is improved when the alternate switching technique is used, and the reverse voltage vectors are rarely selected. Figure 7 depicts the worse case situation at the phase voltage compared to Figure 6, in which the system is operated with a smaller hysteresis band, making it easier to exceed the torque reference and hysteresis band limit. It is proven that the alternate switching technique allows the torque to be regulated uniformly even in the smaller size of the hysteresis band.

\subsection{Experimental results}

The complete DTC drive system, as in Figure 8, is set up to verify the proposed alternate switching technique experimentally. A three-phase two-level inverter drives the induction motor, while the load unit used in this system is the DC motor. Note that the load is proportional to the DC motor speed with additional resistive load. The main controller for this study is the dSPACE 1104, while the optimum sampling period for this device is $50 \mu \mathrm{s}$ [70].

For the experimental results, the same measurements are taken for the torque performance, phase voltage, and inverter switching status for both conventional DTC and proposed alternate switching techniques. Figure 9 (a) shows the waveform capture under the duration of $40 \mathrm{~ms}$. It is noticeable that the torque condition in the conventional DTC is very high in ripple, which has significantly reduced when the alternate switching technique is employed. Here, the torque starts to oscillate regularly under the torque reference.

Figure 9 (b) shows the magnified version, which shows that the torque pattern changes drastically and in a uniform zig-zag pattern. As illustrated previously in Figure 4 (b), the torque increment, $T_{e}{ }^{+}$and decrement, $T_{e}{ }^{-}$now have a shorter time. The phase voltage and inverter switching status also start to operate in a high pulsation, but it does not change the initial condition of the DTC switching concept. This is due to the high pulsation operated under the same sequence as the conventional DTC, as shown in Figure 3.

The same investigation with lower hysteresis band size is tested for experimental testing, where the results are shown in Figures 10 (a) and 10 (b). The condition of torque in Figure 10 (a) suffers even higher ripple compared to torque ripple in Figure 9 (a) during the conventional DTC operation. In the same situation, when the alternate switching is employed, the torque ripple reduces significantly and follows the torque reference condition. As mentioned in section 3, the inverter switching status of the proposed technique will follow the same pattern of the conventional DTC scheme but with an alternate switching condition as in Figure 10 (b). The torque pattern during the alternate switching technique is also in a uniform zig-zag pattern and rarely crosses the torque reference [71].

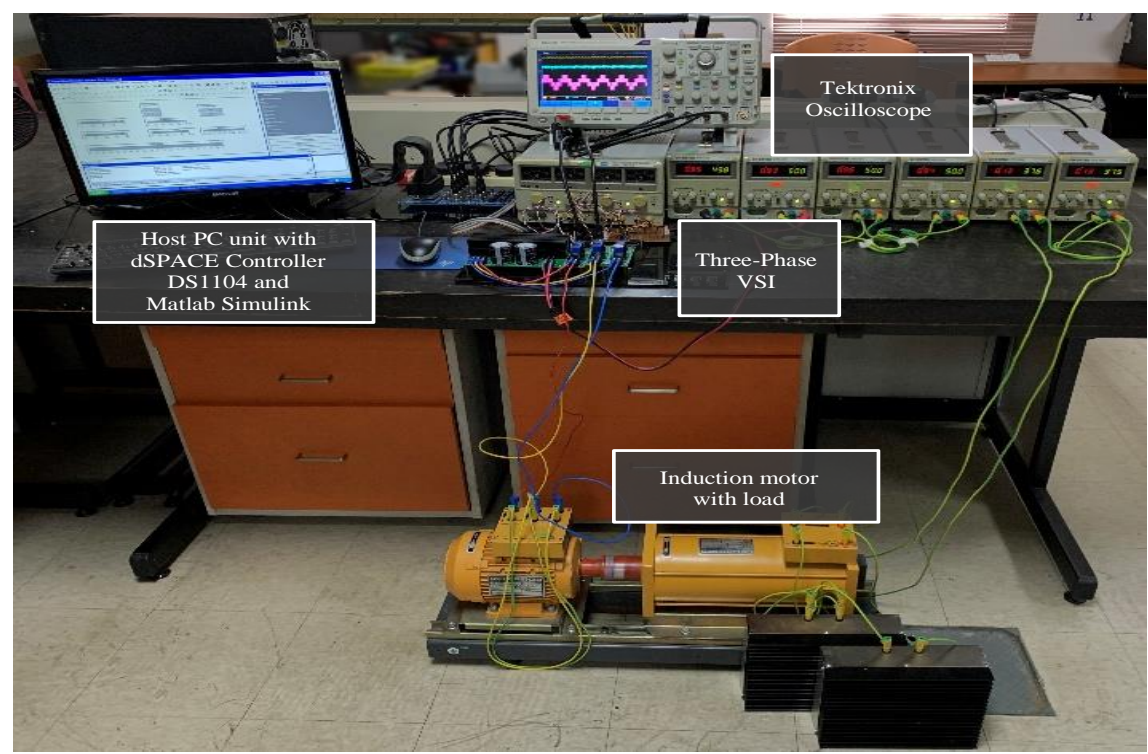

Figure 8. Experimental setup of DTC drive system 


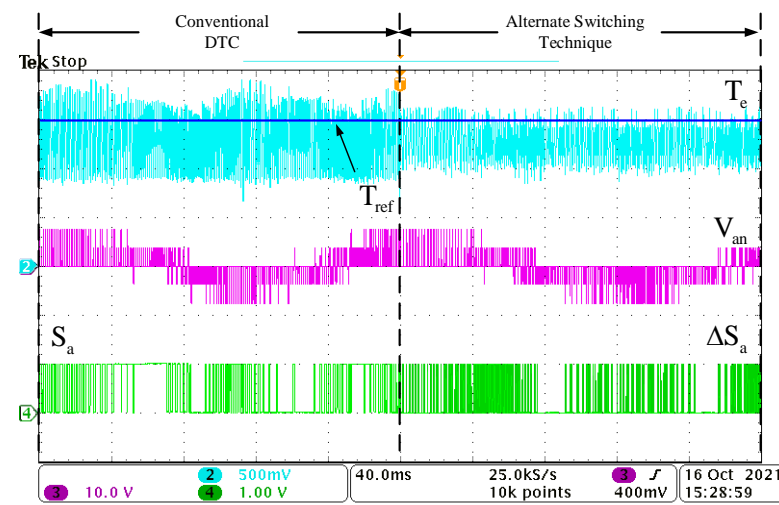

(a)

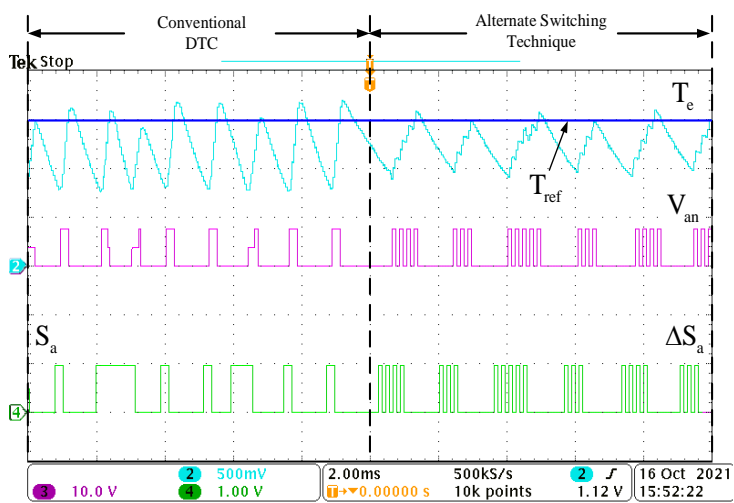

(b)

Figure 9. The performance of torque, phase voltage and inverter switching status under hysteresis band size $0.50 \mathrm{Nm}$. (a) full scale and (b) magnified scale

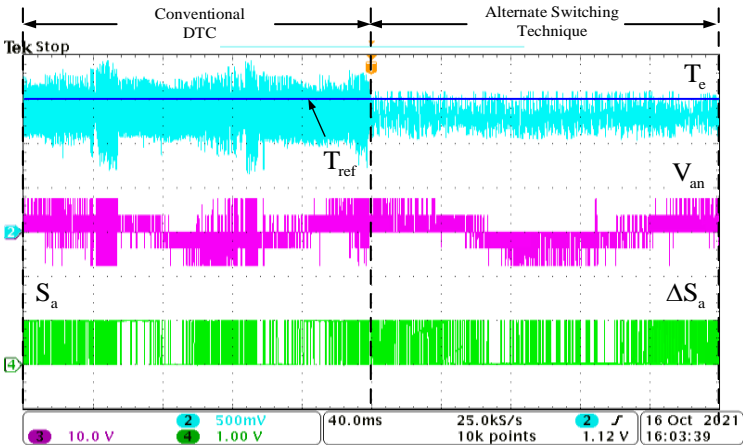

(a)

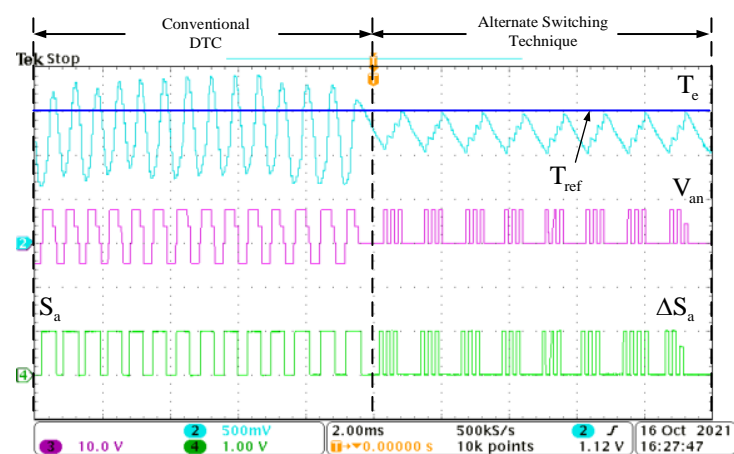

(b)

Figure 10. The performance of torque, phase voltage and inverter switching status under hysteresis band size $0.25 \mathrm{Nm}$. (a) full scale and (b) magnified scale

\section{CONCLUSION}

This paper proposes a novel and effective method to reduce the torque ripple in induction motor drives during low-speed operation. The proposed technique converts the standard voltage vectors into pulsation voltage vectors where the active and zero voltage vectors are separated into smaller widths, allowing the rate of torque increment and decrement to be reduced. By following the pulsation pattern, the increment of torque is now in a zig-zag pattern. This prevents the torque from crossing the torque reference and hysteresis band limit, which helps restrict the system from selecting the reserve voltage vectors. With this pattern, the proposed alternate switching technique in DTC promises the system to operate with regulated torque with less ripple and better frequency variations compared to the conventional DTC system. The viability of the proposed DTC has been demonstrated using MATLAB/Simulink and proven through lab-scale experimental assessment. The reduction in torque ripple using the alternate switching technique has significantly reduced over $40 \%$ in the low-speed operation while maintaining the basic structure of conventional DTC.

\section{REFERENCES}

[1] I. Takahashi and T. Noguchi, "A New Quick-Response and High-Efficiency Control Strategy of an Induction Motor," IEEE Trans. Ind. Appl., vol. IA-22, no. 5, pp. 820-827, 1986, doi: 10.1109/TIA.1986.4504799.

[2] B. Farid, B. Tarek, and B. Sebti, "Fuzzy super twisting algorithm dual direct torque control of doubly fed induction machine," Int. J. Electr. Comput. Eng., vol. 11, no. 5, pp. 3782-3790, 2021, doi: 10.11591/ijece.v11i5.pp3782-3790.

[3] H. Muazzam, M. K. Ishak, and A. Hanif, "Compensating the performance of permanent magnet synchronous machines for fully electric vehicle using lpv control," Bull. Electr. Eng. Informatics, vol. 10, no. 4, pp. 1923-1929, 2021, doi: 10.11591/EEI.V10I4.2946.

[4] Y. Ihedrane, C. El Bekkali, M. El Ghamrasni, S. Mensou, and B. Bossoufi, "Improved wind system using non-linear power control," Indones. J. Electr. Eng. Comput. Sci., vol. 14, no. 3, pp. 1148-1158, 2019, doi: 10.11591/ijeecs.v14.i3.pp1148-1158.

[5] J.-D. Tan, S.-P. Koh, S.-K. Tiong, K. Ali, and A. Abdalla, "Fuzzy logic enhanced direct torque control with space vector 
modulation,” Indones. J. Electr. Eng. Comput. Sci., vol. 11, no. 2, pp. 704-710, 2018, doi: 10.11591/ijeecs.v11.i2.pp704-710

[6] L. Hellali and S. Belhamdi, "Direct torque control of doubly star induction motor using fuzzy logic speed controller," IAES Int. J. Artif. Intell., vol. 7, no. 1, pp. 42-53, 2018, doi: 10.11591/ijai.v7.i1.pp42-53.

[7] M. Youcef, T. Djilali, S. Moreau, H. Said, and D. Bachir, "Dsp improvement of a vector speed induction motor control with a rst and adaptive fuzzy controller," Bull. Electr. Eng. Informatics, vol. 10, no. 3, pp. 1232-1244, 2021, doi: 10.11591/eei.v10i3.1798.

[8] Y. Dbaghi, S. Farhat, M. Mediouni, H. Essakhi, and A. Elmoudden, "Indirect power control of DFIG based on wind turbine operating in MPPT using backstepping approach,” Int. J. Electr. Comput. Eng., vol. 11, no. 3, pp. 1951-1961, 2021, doi: 10.11591/ijece.v11i3.pp1951-1961.

[9] S. Massoum, A. Meroufel, A. Massoum, and W. Patrice, "DTC based on SVM for induction motor sensorless drive with fuzzy sliding mode speed controller,” Int. J. Electr. Comput. Eng., vol. 11, no. 1, pp. 171-181, 2021, doi: 10.11591/ijece.v11i1.pp171181 .

[10] C. Mendil, M. Kidouche, and M. Z. Doghmane, "Hybrid sliding PID controller for torsional vibrations mitigation in rotary drilling systems," Indones. J. Electr. Eng. Comput. Sci., vol. 22, no. 1, pp. 146-158, 2021, doi: 10.11591/ijeecs.v21.i4.pp146-158.

[11] Y. I. Al Mashhadany, "Virtual reality trajectory of modified puma 560 by hybrid intelligent controller," Bull. Electr. Eng. Informatics, vol. 9, no. 6, pp. 2261-2269, 2020, doi: 10.11591/eei.v9i6.2579.

[12] F. Mehedi, R. Taleb, A. B. Djilali, and A. Yahdou, "SMC based DTC-SVM control of five-phase permanent magnet synchronous motor drive," Indones. J. Electr. Eng. Comput. Sci., vol. 20, no. 1, pp. 100-108, 2020, doi: 10.11591/ijeecs.v20.i1.pp100-108.

[13] H. A. Aroussi, E. M. Ziani, M. Bouderbala, and B. Bossoufi, "Enhancement of the direct power control applied to DFIG-WECS," Int. J. Electr. Comput. Eng., vol. 10, no. 1, pp. 35-46, 2020, doi: 10.11591/ijece.v10i1.pp35-46.

[14] M. E. A. Abdelkoui and A. Hazzab, "Predictive torque control of electric vehicle," Int. J. Electr. Comput. Eng., vol. 9, no. 5, pp. 3522-3530, 2019, doi: 10.11591/ijece.v9i5.pp3522-3530.

[15] A. A. Kadum, "New adaptive hysteresis band width control for direct torque control of induction machine drives," Int. J. Power Electron. Drive Syst., vol. 11, no. 4, pp. 1908-1917, 2020, doi: 10.11591/ijpeds.v11.i4.pp1908-1917.

[16] I. M. Alsofyani and K. B. Lee, "Enhanced Performance of Constant Frequency Torque Controller-Based Direct Torque Control of Induction Machines with Increased Torque-Loop Bandwidth,” IEEE Trans. Ind. Electron., vol. 67, no. 12, pp. 10168-10179, 2020, doi: 10.1109/TIE.2019.2959477.

[17] M. Magdy, S. Abu-Zaid, and M. A. Elwany, "Artificial intelligent techniques based on direct torque control of induction machines," Int. J. Power Electron. Drive Syst., vol. 12, no. 4, p. 2070, 2021, doi: 10.11591/ijpeds.v12.i4.pp2070-2082.

[18] H. Ismail, F. Patkar, A. Jidin, A. Z. Jidin, N. A. N. Azlan, and T. Sutikno, "Constant switching frequency and torque ripple minimization of DTC of induction motor drives with three-level NPC inverter," Int. J. Power Electron. Drive Syst., vol. 8, no. 3, 2017, doi: 10.11591/ijpeds.v8i3.pp1035-1049.

[19] X. Chen, Z. Zhang, L. Yu, and Z. Bian, "An Improved Direct Instantaneous Torque Control of Doubly Salient Electromagnetic Machine for Torque Ripple Reduction," IEEE Trans. Ind. Electron., vol. 68, no. 8, pp. 6481-6492, 2021, doi: 10.1109/TIE.2020.3003596.

[20] A. N. Abdullah and M. H. Ali, "Direct torque control of im using PID controller," Int. J. Electr. Comput. Eng., vol. 10, no. 1, pp. 617-625, 2020, doi: 10.11591/ijece.v10i1.pp617-625.

[21] H. A. Mohamed and H. M. D. Habbi, "Power quality of dual two-level inverter fed open end winding induction motor," Indones. J. Electr. Eng. Comput. Sci., vol. 18, no. 2, pp. 688-697, 2020, doi: 10.11591/ijeecs.v18.i2.pp688-697.

[22] S. E. Rezgui, H. Benalla, and H. Bouhebel, "Hybrid bacteria foraging-particle swarm optimization algorithm in DTC performance improving for induction motor drive," Indones. J. Electr. Eng. Comput. Sci., vol. 22, no. 2, pp. 52-61, 2020, doi: 10.11591/ijeecs.v22.i2.pp52-61.

[23] V. T. Ha, T. T. Minh, N. T. Lam, and N. H. Quang, "Experiment based comparative analysis of stator current controllers using predictive current control and proportional integral control for induction motors," Bull. Electr. Eng. Informatics, vol. 9, no. 4, pp. 1662-1669, 2020, doi: 10.11591/eei.v9i4.2084.

[24] N. Farah et al., "Analysis and investigation of different advanced control strategies for high-performance induction motor drives," TELKOMNIKA Telecommunication, Computing, Electronics and Control, vol. 18, no. 6, pp. 3303-3314, 2020, doi: 10.12928/TELKOMNIKA.v18i6.15342.

[25] E. Lotfi, M. Elharoussi, and E. Abdelmounim, "VHDL design and fpga implementation of direct torque control for induction machines,” Bull. Electr. Eng. Informatics, vol. 10, no. 3, pp. 1220-1231, 2021, doi: 10.11591/eei.v10i3.2345.

[26] P. Q. Khanh and H. P. H. Anh, “Advanced deep flux weakening operation control strategies for IPMSM,” Int. J. Electr. Comput. Eng., vol. 11, no. 5, pp. 3798-3808, 2021, doi: 10.11591/ijece.v11i5.pp3798-3808.

[27] A. H. Shallal, A. F. Nashee, and A. E. Abbas, "Smart actuator for IM speed control with F28335 DSP application," Indones. J. Electr. Eng. Comput. Sci., vol. 24, no. 3, pp. 1421-1431, 2021, doi: 10.11591/ijeecs.v24.i3.pp1421-1431.

[28] W. Xu, M. M. Ali, M. F. Elmorshedy, S. M. Allam, and C. Mu, "One Improved Sliding Mode DTC for Linear Induction Machines Based on Linear Metro,” IEEE Trans. Power Electron., vol. 36, no. 4, pp. 4560-4571, 2021, doi: 10.1109/TPEL.2020.3025184.

[29] A. Berzoy, J. Rengifo, and O. Mohammed, "Fuzzy Predictive DTC of Induction Machines with Reduced Torque Ripple and HighPerformance Operation,” IEEE Trans. Power Electron., vol. 33, no. 3, pp. 2580-2587, 2018, doi: 10.1109/TPEL.2017.2690405.

[30] R. Pothuraju, R. Tejavthu, and A. K. Panda, "Multilevel Inverter fed Direct Torque and Flux Control-Space Vector Modulation of Speed Sensorless Permanent Magnet Synchronous Motor drive with Improved Steady State and Dynamic Characteristics," Int. J. Circuit Theory Appl., 2021, doi: 10.1002/cta.3195.

[31] C. Bharath and S. Mohapatro, "Modified Direct Torque Control Scheme for Induction Machine Using Space Vector Modulation," Lect. Notes Electr. Eng., vol. 616, pp. 135-144, 2021, doi: 10.1007/978-981-16-1978-6_12.

[32] H. Aberkane, D. Sakri, and D. Rahem, "Enhanced finite-state predictive torque control of induction motor using space vector modulation,” Prz. Elektrotechniczny, vol. 97, no. 4, pp. 41-47, 2021, doi: 10.15199/48.2021.04.7.

[33] V. Rathore and K. B. Yadav, "Direct Torque Control of Asymmetrical Multiphase (6-Phase) Induction Motor Using Modified Space Vector Modulation,” Lect. Notes Electr. Eng., vol. 707, pp. 511-516, 2021, doi: 10.1007/978-981-15-8586-9_45.

[34] M. Zhang, L. Shi, H. Zhu, and Y. Li, "A Direct Thrust Control Based on Space Vector Modulation Strategy for Linear Induction Motor," in 23rd International Conference on Electrical Machines and Systems, ICEMS 2020, 2020, pp. 1810-1813, doi: 10.23919/ICEMS50442.2020.9290947.

[35] A. Vujji and R. Dahiya, "Design of PI Controller for Space Vector Modulation based Direct Flux and Torque Control of PMSM Drive," 2020, doi: 10.1109/ICMICA48462.2020.9242812.

[36] S. Zhong, "Evaluation of doubly-fed wind turbine with direct torque controller under space vector modulation and matrix transformation," Int. J. Mechatronics Appl. Mech., vol. 1, no. 8, pp. 48-55, 2020.

[37] A. H. Kumar and R. Ramchand, "Analysis on the Extend of Application of Artificial Neural Networks in Direct Torque ControlSpace Vector Modulated Drives,” 2020, doi: 10.1109/PESGRE45664.2020.9070461. 
[38] C. Haitam, E. Ahmed, and N. Tamou, "Advanced modified direct torque control with space vector modulation based on active disturbance rejection control for induction motor sensorless drive," Int. J. Mech. Eng. Robot. Res., vol. 9, no. 1, pp. 13-19, 2020, doi: 10.18178/ijmerr.9.1.13-19.

[39] A. K. Peter and J. Mathew, "Rotor Parameter Independent Carrier Space Vector Modulated Direct Torque Control of Induction Motor,” 2019, doi: 10.1109/ITEC-India48457.2019.ITECIndia2019-250.

[40] M. Sellah, A. Kouzou, M. Mohamed-Seghir, M. M. Rezaoui, R. Kennel, and M. Abdelrahem, "Improved DTC-SVM based on input-output feedback linearization technique applied on DOEWIM powered by two dual indirect matrix converters," Energies, vol. 14, no. 18, 2021, doi: 10.3390/en14185625.

[41] A. K. Peter and J. Mathew, "Bus clamped Space Vector Pulse Width Modulated Direct Torque Control of Induction Motor," in Proceedings of 2019 IEEE Region 10 Symposium, TENSYMP 2019, 2019, pp. 508-513, doi: 10.1109/TENSYMP46218.2019.8971311.

[42] H. Setiana, F. Husnayain, and F. Yusivar, "Speed Sensorless Control of Dual Induction Motor using Direct Torque Control - Space Vector Modulation," in 2019 IEEE 2nd International Conference on Power and Energy Applications, ICPEA 2019, 2019, pp. 110114, doi: 10.1109/ICPEA.2019.8818504

[43] B. Siro, C. Ianache, and A. Savulescu, "Space Vector PWM-DTC in an application for crude oil extraction in Canadian version," 2019, doi: 10.1109/ECAI.2018.8678996.

[44] G. Rafajlovski, M. Digalovski, and G. Cvetkovski, "Space vector modulation techniques for improved stator flux trajectory in direct torque control of induction motor [Techniki modulacji wektora przestrzennego dla poprawy trajektorii strumienia stojana w bezpośrednim sterowaniu momentem obrotowym silnika indukcyjnego]," Prz. Elektrotechniczny, vol. 95, no. 5, pp. 14-17, 2019, doi: 10.15199/48.2019.05.04.

[45] F. Benmessaoud, A. Chikhi, and S. Belkacem, "Fuzzy Compensator of the Stator Resistance Variation of the DTC Driven Induction Motor Using Space Vector Modulation,” Adv. Intell. Syst. Comput., vol. 845, pp. 89-97, 2019, doi: 10.1007/978-3-319-99010-1_8.

[46] K. A. Chinmaya and G. K. Singh, "Experimental analysis of various space vector pulse width modulation (SVPWM) techniques for dual three-phase induction motor drive," Int. Trans. Electr. Energy Syst., vol. 29, no. 1, 2019, doi: 10.1002/etep.2678.

[47] Z. M. Tahir, A. Jidin, and M. L. M. Jamil, "Multi-carrier switching strategy for high-bandwidth potential balancing control of multilevel inverters," Int. J. Power Electron. Drive Syst., vol. 12, no. 4, pp. 2384-2392, 2021, doi: 10.11591/ijpeds.v12.i4.pp23842392.

[48] K. V. Praveenkumar and T. Vinay Kumar, "Space Vector Modulated Direct Torque Control of an Open-end Winding Induction Motor Drive with Three-Level Inversion,” in IECON Proceedings (Industrial Electronics Conference), 2021, vol. 2021-October, doi: 10.1109/IECON48115.2021.9589493.

[49] M. E. Mahfoud, B. Bossoufi, N. E. Ouanjli, M. Said, and M. Taoussi, "Improved Direct Torque Control of Doubly Fed Induction Motor Using Space Vector Modulation,” Int. J. Intell. Eng. Syst., vol. 14, no. 3, pp. 177-188, 2021, doi: 10.22266/ijies2021.0630.16.

[50] A. Mohan, M. Khalid, and A. C. Binojkumar, "Performance Analysis of Permanent Magnet Synchronous Motor under DTC and Space Vector-based DTC schemes with MTPA control," 2021, doi: 10.1109/ICCISc52257.2021.9484869.

[51] T. A. Hussein and L. A. Mohammed, "Detailed Simulink implementation for induction motor control based on space vector pulse width modulation SVPWM," Indones. J. Electr. Eng. Comput. Sci., vol. 22, no. 3, pp. 1251-1262, 2021, doi: 10.11591/ijeecs.v22.i3.pp1251-1262.

[52] C. Hicham, A. Nasri, and K. Kayisli, "A novel method of electric scooter torque estimation using the space vector modulation control," Int. J. Renew. Energy Dev., vol. 10, no. 2, pp. 355-364, 2021, doi: 10.14710/ijred.2021.33403.

[53] F. Mehedi, H. Benbouhenni, L. Nezli, and D. Boudana, "Feedforward neural network-DTC of multi-phase permanent magnet synchronous motor using five-phase neural space vector pulse width modulation strategy," J. Eur. des Syst. Autom., vol. 54, no. 2, pp. 345-354, 2021, doi: 10.18280/JESA.540217.

[54] B. D. Lemma and S. Pradabane, "Ripple torque lessening in space vector pulse width modulation based direct torque control of permanent magnet synchronous motor drive," in Journal of Physics: Conference Series, 2021, vol. 1817, no. 1, doi: 10.1088/1742$6596 / 1817 / 1 / 012027$.

[55] R. B. Jonnala and C. Sai Babu, "A Modified Multiband Hysteresis Controlled DTC of Induction Machine with 27-level asymmetrical CHB-MLI with NVC modulation," Ain Shams Eng. J., vol. 9, no. 1, pp. 15-29, 2018, doi: 10.1016/j.asej.2015.08.007.

[56] S. Lakhimsetty, V. S. P. Satelli, R. S. Rathore, and V. T. Somasekhar, "Multilevel Torque Hysteresis-Band Based Direct-Torque Control Strategy for a Three-Level Open-End Winding Induction Motor Drive for Electric Vehicle Applications," IEEE J. Emerg. Sel. Top. Power Electron., vol. 7, no. 3, pp. 1969-1981, 2019, doi: 10.1109/JESTPE.2018.2870382.

[57] N. R. N. Idris and A. H. M. Yatim, "Direct torque control of induction machines with constant switching frequency and reduced torque ripple," IEEE Trans. Ind. Electron., vol. 51, no. 4, pp. 758-767, 2004, doi: 10.1109/TIE.2004.831718.

[58] A. Jidin, N. R. N. Idris, A. H. M. Yatim, T. Sutikno, and M. E. Elbuluk, “An optimized switching strategy for quick dynamic torque control in DTC-hysteresis-based induction machines," IEEE Trans. Ind. Electron., vol. 58, no. 8, pp. 3391-3400, 2011, doi: 10.1109/TIE.2010.2087299.

[59] S. A. A. Tarusan, A. Jidin, M. L. M. Jamil, K. A. Karim, and T. Sutikno, "A review of direct torque control development in various multilevel inverter applications," International Journal of Power Electronics and Drive Systems, vol. 11, no. 3. pp. 1675-1688, 2020, doi: 10.11591/IJPEDS.V11.I3.PP1675-1688.

[60] H. T, A. V. R. Teja, G. Bhuvaneswari, and B. Singh, "Performance enhancement in a multilevel inverter fed PTC induction motor drive by optimal voltage vector selection," Int. J. Power Electron. Drive Syst., vol. 10, no. 2, p. 801, 2019, doi: 10.11591/ijpeds.v10.i2.pp801-812.

[61] K. Xia, Y. Ye, J. Ni, Y. Wang, and P. Xu, "Model predictive control method of torque ripple reduction for BLDC Motor," IEEE Trans. Magn., vol. 56, no. 1, pp. 1-6, 2020, doi: 10.1109/TMAG.2019.2950953.

[62] Y. Cho, Y. Bak, and K. B. Lee, "Torque-Ripple Reduction and Fast Torque Response Strategy for Predictive Torque Control of Induction Motors," IEEE Trans. Power Electron., vol. 33, no. 3, pp. 2458-2470, 2018, doi: 10.1109/TPEL.2017.2699187.

[63] Y. N. Tatte and M. V Aware, "Torque Ripple and Harmonic Current Reduction in a Three-Level Inverter-Fed Direct-TorqueControlled Five-Phase Induction Motor,” IEEE Trans. Ind. Electron., vol. 64, no. 7, pp. 5265-5275, 2017, doi: 10.1109/TIE.2017.2677346.

[64] A. Nasr, C. Gu, X. Wang, G. Buticchi, S. Bozhko, and C. Gerada, "Torque-Performance Improvement for Direct Torque-Controlled PMSM Drives Based on Duty-Ratio Regulation," IEEE Trans. Power Electron., vol. 37, no. 1, pp. 749-760, 2022, doi: 10.1109/TPEL.2021.3093344.

[65] N. Yan, X. Cao, and Z. Deng, "Direct torque control for switched reluctance motor to obtain high torque-ampere ratio," IEEE Trans. Ind. Electron., vol. 66, no. 7, pp. 5144-5152, 2019, doi: 10.1109/TIE.2018.2870355.

[66] X. Wu, W. Huang, X. Lin, W. Jiang, Y. Zhao, and S. Zhu, "Direct Torque Control for Induction Motors Based on Minimum Voltage 
Vector Error,” IEEE Trans. Ind. Electron., vol. 68, no. 5, pp. 3794-3804, 2021, doi: 10.1109/TIE.2020.2987283.

[67] P. Rajasekaran and V. J. Senthilkumar, "An improved DTFC based five levels - NPC inverter fed induction motor for torque ripple minimization," International Journal of Power Electronics and Drive Systems, vol. 7, no. 2. pp. 531-542, 2016, doi: 10.11591/ijpeds.v7.i2.pp531-542.

[68] S. S. Hakami, I. M. Alsofyani, and K. B. Lee, "Torque Ripple Reduction and Flux-Droop Minimization of DTC with Improved Interleaving CSFTC of im Fed by Three-Level NPC Inverter," IEEE Access, vol. 7, pp. 184266-184275, 2019, doi: 10.1109/ACCESS.2019.2960685.

[69] S. Allirani, N. Subha Lakshmi, and H. Vidhya, "Performance analysis on direct torque controlled induction motor drive with varying hysteresis controller bandwidth," International Journal of Power Electronics and Drive Systems, vol. 11, no. 3. pp. 1165-1174, 2020, doi: 10.11591/ijpeds.v11.i3.pp1165-1174.

[70] N. Venkataramana Naik and S. P. Singh, "A Comparative Analytical Performance of F2DTC and PIDTC of Induction Motor Using DSPACE-1 104,” IEEE Trans. Ind. Electron., vol. 62, no. 12, pp. 7350-7359, 2015, doi: 10.1109/TIE.2015.2463758.

[71] B. Singh, G. Bhuvaneswari, and S. Madishetti, "Power quality improvement in DTC based induction motor drive using Minnesota rectifier," 2011, doi: 10.1109/ICPES.2011.6156685.

\section{BIOGRAPHIES OF AUTHORS}

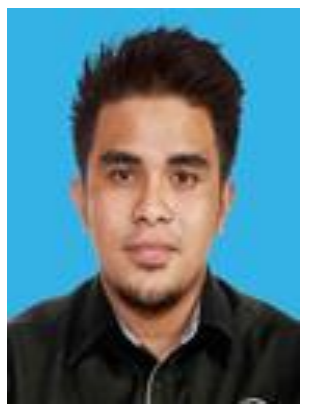

Muhammad Zaid Aihsan (D) 8 SC $\mathrm{P}$ received the B.Eng. and M.Sc. degrees in Electrical Engineering from Universiti Malaysia Perlis, Malaysia, in 2013 and 2016, respectively. He is currently working on the Ph.D. degree under Power Electronics and Drives Research Group (PEDG) in the Faculty of Electrical Engineering, Universiti Teknikal Malaysia Melaka (UTeM), Malaysia. He is a Lecturer at Universiti Malaysia Perlis (UniMAP), Malaysia. His research interests include the power electronics and motor drive systems. He can be contacted atemail: zaid@unimap.edu.my.

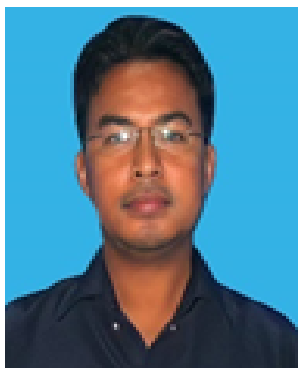

Auzani Jidin (I) 8D SC P received the B.Eng. degrees, M.Eng. degrees and Ph.D. degree in power electronics and drives from Universiti Teknologi Malaysia, Johor Bahru, Malaysia, in 2002, 2004 and 2011, respectively. He is currently an academician in Faculty of Electrical Engineering, Universiti Teknikal Malaysia Melaka, Melaka, Malaysia. He is also an active researcher in Power Electronics and Drives Research Group (PEDG) that established under the same faculty. His research interests include power electronics, motor drive systems, fieldprogrammable gate array, and DSP applications. He can be contacted at email: auzani@utem.edu.my.

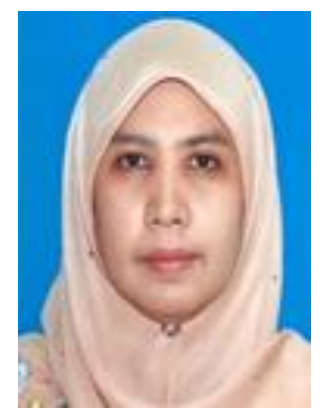

Azrita Alias (D) 8d SC P received her B. Eng in Electrical (Control and Instrumentation) (Hons) and M. Eng (Electrical) from the Universiti Teknologi Malaysia, in 2000 and 2003, respectively, and her PhD from University of Malaya in 2015. She is a senior lecturer at the Faculty of Electrical Engineering, Universiti Teknikal Malaysia Melaka (UTeM). Her main research interests are in modeling, control systems design and power electronics application in engineering systems. She can be contacted at email: azrita@utem.edu.my.

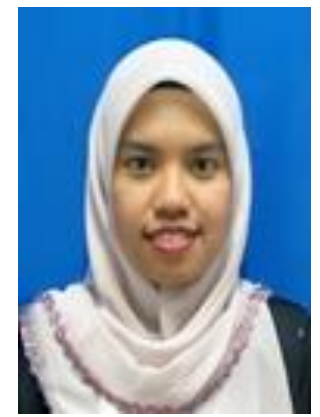

Siti Azura Ahmad Tarusan (D) SC P received the B.Eng. degrees from Universiti Teknologi Malaysia, Johor Bahru, Malaysia, in 2008 and M.Eng. degrees from Universiti Malaya, Malaysia, in 2012. She is currently an academician in Faculty of Electrical Engineering, Universiti Teknikal Malaysia Melaka, Melaka, Malaysia. She is also an active researcher in Power Electronics and Drives Research Group (PEDG) that established under the same faculty. Her research interests include power electronics and motor drive systems. She can be contacted at email: sitiazura@utem.edu.my. 

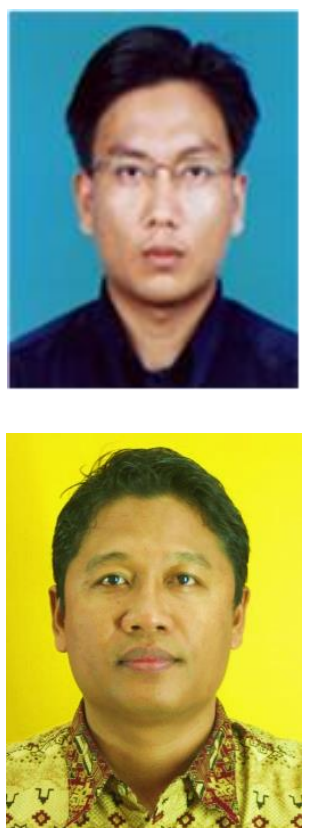

Zuraidi Md Tahir (ID 8d SC P Z. M. Tahir received the B.Eng. degrees from Universiti Teknologi Malaysia, Johor Bahru, Malaysia, in 2002 and M.Eng. degrees from Universiti Tun Hussien Onn, Malaysia, in 2013. He is currently pursuing PhD under Power Electronics and Drives Research Group (PEDG) in the Faculty of Electrical Engineering, Universiti Teknikal Malaysia Melaka, Melaka, Malaysia. His research interests include power electronics and motor drive systems. He can be contacted at email: zuraidi79@yahoo.com.

Tole Sutikno (iD) SC P is a lecturer in Electrical Engineering Department at the Universitas Ahmad Dahlan (UAD), Yogyakarta, Indonesia. He received his B.Eng., M.Eng. and Ph.D. degrees in Electrical Engineering from Universitas Diponegoro, Universitas Gadjah Mada and Universiti Teknologi Malaysia, in 1999, 2004 and 2016, respectively. He has been an Associate Professor in UAD, Yogyakarta, Indonesia since 2008. He is currently an Editor-in-Chief of the TELKOMNIKA and the Head of the Embedded Systems and Power Electronics Research Group. His research interests include the field of digital design, industrial applications, industrial electronics, industrial informatics, power electronics, motor drives, renewable energy, FPGA applications, embedded system, artificial intelligence, intelligent control, information technology and digital library. He can be contacted at email: tole@ee.uad.ac.id. 